\title{
Floristic Composition, Grazing Effects and Above-ground Plant Biomass in the Hulunbeier Grasslands of Inner Mongolia, China
}

\author{
Kawada, Kiyokazu ${ }^{1+}$, Mayu Kurosu², Yunxiang Cheng $^{2 \ddagger}$, Tsagaanbandi Tsendeekhuu ${ }^{3}$, \\ Wuyunna $^{4}$, Toru Nakamura ${ }^{2}$ and Ichiroku Hayashi ${ }^{5 *}$ \\ ${ }^{1}$ National Institute for Agro-Environmental Sciences, 313 Kannon-dai, Tsukuba, Ibaraki, Japan \\ ${ }^{2}$ Graduate School of Life and Environmental Sciences, University of Tsukuba, Tsukuba, Ibaraki, Japan \\ ${ }^{3}$ Department of Botany, Faculty of Biology, National University of Mongolia, P. O. Box 767, Ulaanbaatar 46, Mongolia \\ ${ }^{4}$ Department of Environmental Engineering, College of Life Science, Dalian Nationalities University \\ ${ }^{5}$ 173-5 Kosato, Ueda, Nagano, Japan, 386-0005
}

\begin{abstract}
In order to assess the effect of grazing on grasslands using floristic composition, we studied the floristic composition and plant biomass of steppe vegetation in Hulunbeier, Inner Mongolia. The dominant species of the grasslands were Stipa krylovii, Stipa grandis and Leymus chinensis. Floristic composition changed according to grazing pressure, being light, heavy and moderate. Under heavy grazing conditions, the importance value of $P$. acaulis, $C$. korshinskyi and Cleistogenes squarrosa increased in the plant community. These species were indicators of heavily grazed stand. Plant biomass of the stands ranged within $11.6 \mathrm{~g} \mathrm{~m}^{-2}$ and $63.5 \mathrm{~g} \mathrm{~m}^{-2}$ and $69.5 \mathrm{~g} \mathrm{~m}^{-2}$ and $166.2 \mathrm{~g} \mathrm{~m}^{-2}$ to the west and east of Lake Hulun, respectively. These values are equivalent to ca. $450 \sim 1,000 \mathrm{~kg}$ of atmospheric carbon per hector, which is retained within the stand during the summer season.
\end{abstract}

Key words: Floristic composition, Grassland, Inner Mongolia, Plant biomass

\section{INTRODUCTION}

The grasslands in eastern Inner Mongolia are located in the interior of Eurasian continent. Although land use in the area has historically been nomadic, there has been a shift among the nomadic people in the region toward permanent settlement. This shift in land use has had a marked impact on the grassland ecosystem of the region (Burensain 2001).

The relatively low population density in Hulunbeier has meant that, compared to other regions in Inner Mongolia, the grasslands in Hulunbeier have been reasonably well conserved (Zhou et al. 1995). Precipitation on the Hulunbeier grasslands increases from west to east because eastern Hulunbeier, which covered by forest steppe, is adjacent to the Da Hinggan Ling mountain range (Liu et al. 1994). Since floristic composition and plant biomass are markedly affected by precipitation, we examined the effects of grazing intensity on the grasslands in Hulunbeier from west to east in areas with different precipitation.

We have conducted an ecological study on the Mongolian steppe to determine how these grasslands could be utilized in a sustainable manner (Hayashi et al. 1988). Numerous studies have been conducted to date on degradation of the grassland in Xilingole, Keerqin sand-land and Hulunbeier in Inner Mongolia and Kazakhstan (Hayashi et al. 1988, 2006, 2008, Nakamura et al. 1988, Kawanabe et al. 1998, Wuyunna et al. 1999). In this study, we undertook a preliminary study on floristic composition and plant biomass of the grassland in the region. Floristic composition of the plant community indicates the stand quality under the environments of climatic change and human activities (Nakamura et al. 2000, Yiruhan et al. 2001).

The findings of the study could be applied to assessing the impact of both environmental conditions and grazing pressure on differences in floristic composition and plant biomass.

\section{STUDY SITES AND METHODS}

\section{Study Sites}

The study sites in Hulunbeier were located at a latitude of $48^{\circ}$ $29^{\prime} \sim 49^{\circ} 34^{\prime} \mathrm{N}$ and a longitude of $116^{\circ} 35^{\prime} \sim 120^{\circ} 12^{\prime} \mathrm{E}$. We selected three study sites to the west of Lake Hulun side and three sites including three study stands of Ewenke Somu to the east of the lake (Fig. 1). At each site, samples were taken in areas consi-

\footnotetext{
* Corresponding author; Phone: +81-268-24-4344, e-mail: ihayashi@coral.ocn.ne.jp

+ Present address; Alliance for Research on North Africa, The University of Tsukuba, 1-1-1 Tennodai, Tsukuba, Ibaraki, 305-8572, Japan

₹ Present address; Arid Land Research Center, Tottori University, 1390 Hamasaka, Tottori 680-0001, Japan
} 


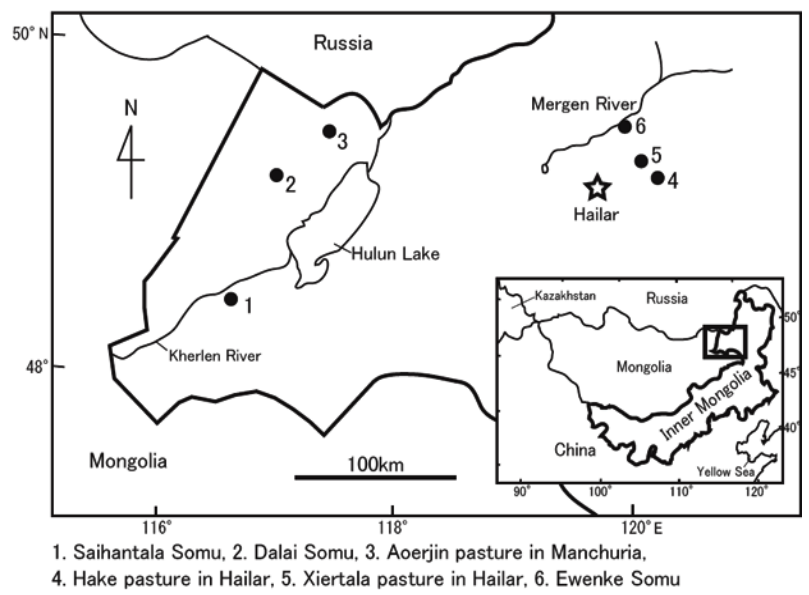

Fig. 1. Locations of study sites in Hulunbeier, Inner Mongolia. 1. Saihantala Somu, 2. Dalai Some, 3. Aoerjin pasture in Manchuria, 4. Hake pasture in Hailar, 5. Xiertala pasture in Hailar, 6. Ewenke Somu.

dered to be homogenous with respect to physiognomy. Measurements were carried out in an intensively grazed, lightly grazed and moderately grazed stands, which were assessed depending on vegetation coverage and plant height of the stands. In addition, we also collected data from a stand that was used for mowing to the east of the lake.

Study sites were selected after a preliminary survey of areas considered to be representative of the steppe environment in Hulunbeier, and were located at Saihantala Somu (Saihantala), Dalai So$\mathrm{mu}$ (Dalai), Aoerjin pasture in Manchuria (Aoerjin), Ewenke Somu (Ewenke 1, 2, 3), Xiertala pasture (Xiertala) in Hailar and Hake pasture in Hailar (Hake) (Fig. 2). In Ewenke around the Mergen Ri-

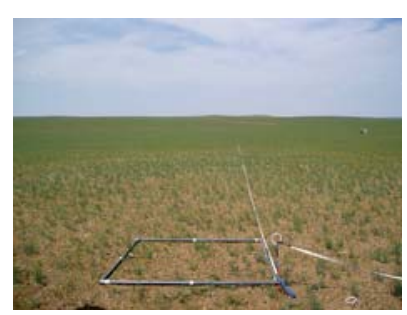

(a) Saihantala Somu

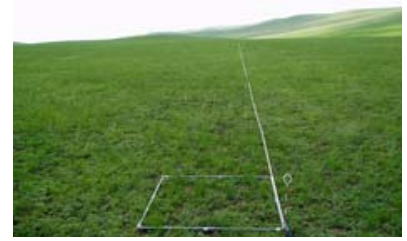

(c) Ewenke Somu 1 pasture

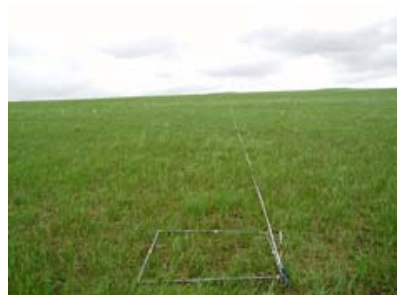

(b) Aoerjin pasture in Manchuria

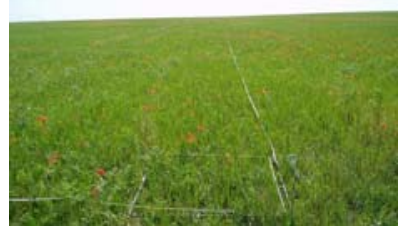

(d) Xiertala in Hailar
Fig. 2. Landscape of study stands. ver, three stands were studied along a gradient of pressure of grazing. Assessing the coverage of vegetation and floristic composition of the stands, the stands were designated as having been subjected to heavy, moderate and light grazing, which varied in response to their distance from the Mergen River which was used by livestock as a water source. Table 1 shows the characteristics of each of the study sites including location, precipitation and mean annual temperature. The stands were situated on a gently rolling plain ranging in altitude between $600 \mathrm{~m}$ and $749 \mathrm{~m}$ above sea level. The flora of the stands was considered typical for the steppe environment and was dominated by species belonging to the genus Stipa. The stands were used for livestock grazing and the soil type at the sites consisted of ksatanozem and chernozem soils. The mean annual temperatures and precipitation at these sites ranged between $0.9^{\circ} \mathrm{C}$ and $225.4 \mathrm{~mm}$ at Saihantala and $0.2^{\circ} \mathrm{C}$ and $317.0 \mathrm{~mm}$ in Hailar (Institute of Meteorology and Hydrology of Inner Mongolia 2006). The monthly change in temperature and precipitation in Hailar is shown in Fig. 3. The climatic regime of the region is favorable for plant growth because most of the rainfall occurs in summer. The study was conducted from 1 to 19 July 2006.

\section{METHODS}

We measured plant height and coverage for each species in five to ten $1 \mathrm{~m}^{2}$ quadrats at intervals of $10 \mathrm{~m}$ along two transects set $10 \mathrm{~m}$ apart. After recording the species in the quadrat, we measured the height of the highest plant and the coverage of each species. Coverage was measured using the Penfound-Howard method modified by Numata (1987). Numata's summed dominance ratio (SDR) was determined from the measurements of plant height, coverage and occurrence frequency (Hayashi et al. 2006).

We obtained biomass data using direct measurements and an estimation technique using a numerical model. The aboveground plant biomass of the stands was determined by clipping the individual plants at the base and then assigning their species. Litter, including standing litter, in the stand was also collected. The aboveground plant biomass for each species was then weighed after drying for 24 hours in an oven at $80^{\circ} \mathrm{C}$. In order to estimate the plant biomass in the stand without clipping plants, we determined the $v$-value proposed by Kawada et al. (2005). The $v$-value is derived by multiplying plant height $(\mathrm{cm})$ by the coverage evaluated using Penfound-Howard-Numata criteria; the unit of the $v$-value is $\mathrm{cm}^{3}$. In calculation, the coverage mentioned above was converted as follows: 4: $8,800 \mathrm{~cm}^{2}, 3: 6,300 \mathrm{~cm}^{2}, 2: 3,800 \mathrm{~cm}^{2}, 1: 1,600 \mathrm{~cm}^{2}, 0.2$ : $300 \mathrm{~cm}^{2}$ and 0.04: $50 \mathrm{~cm}^{2}$ (Numata 1987). We derived an equation to show the relationship between plant biomass and the $v$-value. Using the equation we were able to estimate the plant biomass of 
Table 1. Summarized information for the studied sites in the grasslands in Inner Mongolia

\begin{tabular}{|c|c|c|c|c|c|c|c|c|}
\hline Study site number & No.1 & No.2 & No.3 & No.4 & No.5 & No.6 & No.7 & No.8 \\
\hline Study site & $\begin{array}{l}\text { Saihantala } \\
\text { Somu }\end{array}$ & $\begin{array}{l}\text { Dalai } \\
\text { Somu }\end{array}$ & $\begin{array}{l}\text { Aoerjin pasture } \\
\text { in Manchuria }\end{array}$ & $\begin{array}{c}\text { Hake pasture } \\
\text { in Hailar }\end{array}$ & $\begin{array}{l}\text { Xiertala pas- } \\
\text { ture in Hailar }\end{array}$ & $\begin{array}{l}\text { Ewenke } \\
\text { Somu } 1\end{array}$ & $\begin{array}{l}\text { Ewenke } \\
\text { Somu } 2\end{array}$ & $\begin{array}{l}\text { Ewenke } \\
\text { Somu } 3\end{array}$ \\
\hline Latitude & $48^{\circ} 29^{\prime} 24.9^{\prime \prime}$ & $49^{\circ} 14^{\prime} 35.8^{\prime \prime}$ & $49^{\circ} 31^{\prime} 16.5^{\prime \prime}$ & $49^{\circ} 15^{\prime} 15.9^{\prime \prime}$ & $49^{\circ} 17^{\prime} 39.5^{\prime \prime}$ & $49^{\circ} 34^{\prime} 34.0^{\prime \prime}$ & $49^{\circ} 34^{\prime} 25.1^{\prime \prime}$ & $49^{\circ} 34^{\prime} 11.8^{\prime \prime}$ \\
\hline Longitude & $116^{\circ} 35^{\prime} 14.6^{\prime \prime}$ & $116^{\circ} 55^{\prime} 26.6^{\prime \prime}$ & $117^{\circ} 20^{\prime} 31.2^{\prime \prime}$ & $120^{\circ} 12^{\prime} 50.6^{\prime \prime}$ & $119^{\circ} 58^{\prime} 12.2^{\prime \prime}$ & $119^{\circ} 55^{\prime} 38.1^{\prime \prime}$ & $119^{\circ} 55^{\prime} 56.9^{\prime \prime}$ & $119^{\circ} 55^{\prime} 43.0^{\prime \prime}$ \\
\hline Altitude (m) & 600 & 734 & 749 & 645 & 720 & 653 & 702 & 661.5 \\
\hline Slope $\left(^{\circ}\right)$ & 4 & 0 & 3 & 13 & 0 & 6 & 4 & 3 \\
\hline Direction & $\mathrm{NE}$ & - & NW & NW & - & SW & SE & NW \\
\hline $\begin{array}{l}\text { Annual mean Tem- } \\
\text { perature }\left({ }^{\circ} \mathrm{C}\right)\end{array}$ & 0.9 & 0.4 & 0.4 & 0.2 & 0.2 & 0.2 & 0.2 & 0.2 \\
\hline $\begin{array}{l}\text { Annual precipitation } \\
(\mathrm{mm})\end{array}$ & 225.4 & 196.6 & 196.6 & 317.0 & 317.0 & 317.0 & 317.0 & 317.0 \\
\hline Soil type & Kastanozem & Kastanozem & Kastanozem & Chernozem & Kastanozem & Kastanozem & Kastanozem & Kastanozem \\
\hline Soil hardness (mm) & 16.4 & 18.8 & 14.4 & 17.2 & 15.4 & 18.8 & 18.6 & 18.4 \\
\hline Soil moisture (\%) & 11.4 & 8.5 & 17.3 & 16.8 & 22.5 & 16.0 & 14.0 & 12.1 \\
\hline Date & 02-Jul-10 & 03-Jul-10 & 05-Jul-10 & 09-Jul-10 & 13-Jul-10 & 17-Jul-10 & 19-Jul-10 & 20-Jul-10 \\
\hline Vegetation cover (\%) & 29.0 & 58.1 & 76.1 & 93.8 & 84.8 & 77.8 & 76.7 & 93.9 \\
\hline Source material & Loess & Loess & Loess & Loess & Loess & Loess & Loess & Loess \\
\hline Dominant species & $\begin{array}{c}\text { Allium } \\
\text { polyrhizum }\end{array}$ & $\begin{array}{l}\text { Stipa } \\
\text { krylovii }\end{array}$ & $\begin{array}{l}\text { Leymus } \\
\text { chinensis }\end{array}$ & L. chinensis & L. chinensis & S. krylovii & S. krylovii & S. krylovii \\
\hline
\end{tabular}

*Temperature and prepicitation (2001 2005) provided by the Institute of Meteorology and Hydrology of Inner Mongolia.

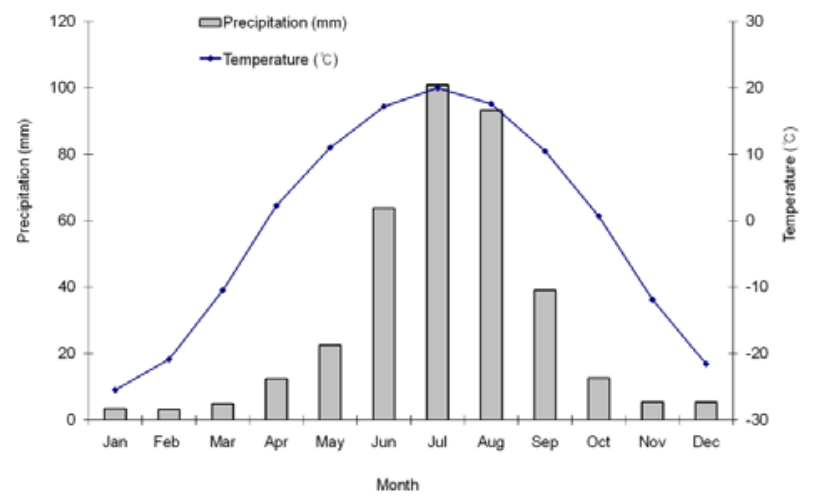

Fig. 3. Monthly change in temperature and precipitation in Hailar.

the stand without destroying the stands.

In studying the plant biomass of the grassland, we adopted following procedure: 1 . The floristic composition of each stand was compared with a floristically homogeneous stand, (What classified was the stand using the floristic composition). 2. In classified stands, quadrat sampling and statistical analysis was undertaken. 3. The mean weight and variance of plant biomass per unit area was calculated with five replications (Huang et al. 2004).

The soil hardness and soil water content were measured using a Yamanaka-type penetrometer (Fujiwara Scientific Company) and a TDR (Time Domain Reflex) soil water meter (Fujiwara Scientific Company) with five replications.

\section{RESULTS}

\section{Sample Size}

Sample size versus cumulative percentage of newly recorded species in successive increases in the number of quadrats in the Mergen River stands is shown in Fig. 4. As shown in the figure, five quadrats were sufficient for including $95 \%$ of the species in the stand. The results were similar to those observed at the five other study sites.

\section{Floristic Composition of the Stands}

The floristic composition of the stands is given in Table 2 with Numata's summed dominance ratio (SDR). The stands were dominated by S. krylovii and $L$. chinensis. The total number of species 


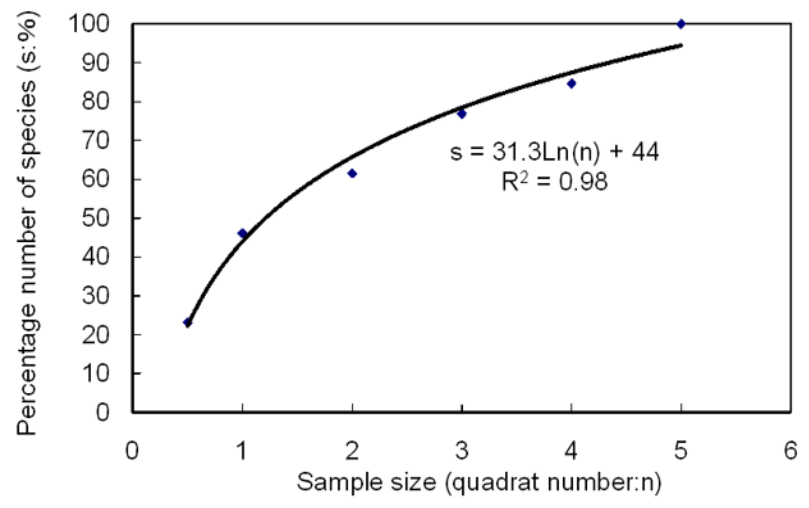

Fig. 4. Sample size versus cumulative percentage of newly recorded species in successively increasing number of quadrats.

at the eight sites was 99 including four unidentified species. The species recorded in all stands are shown in lines 1 to 6 in the table. The dominant species was $S$. krylovii and the stand included $L$. chinensis, Allium tenuissimum, Carex korshinskyi, Cleistogenes squarrosa, Potentilla bifurca and Sibbaldia adpressa. The species recorded exclusively in Saihantala (SHT) were Allium polyrhizum, Euphorbia humifusa and Artemisia pectinata listed in lines 12 to 14. The Saihantala site was the driest and most heavily grazed of all the study sites. Allium bidentatum, Agropyron cristatum and Artemisia frigida were recorded in Dalai (DL) and Ewenke (EWK). The species recorded in the stands from Dalai to Hake are listed in lines 15 to 24 of the table, while species distributed to the east of Ewenke are listed in lines 25 to 27 in the table. Species specific to each stand were listed in lines 28 to 59 and species with a random distribution at study sites are listed below line 60. The stands in Saihantala were dominated by A. polyrhizum, with 17 other species occurring in ten $1 \mathrm{~m}^{2}$ quadrats. The mean plant height and coverage at this study site was $6.5 \mathrm{~cm}$ and $29 \%$. A. bidentatum, A. cristatum and A. frigida were not recorded, although these species were observed in other stands.

The stands in Dalai were dominated by S. krylovii and L. chinensis, with Chenopodium acuminatum having a high ranking and Caragana microphylla being specific to the stand. The important species of the stands in Aoerjin were L. chinensis, S. krylovii and C. korshinskyi, all of which had high SDR values. In addition, Bupleurum scorzonerifolium, A. anisopodium, Chenopodium aristatum and $S$. grandis were observed in high frequency; the latter two species were only recorded in the stands at Aoerjin. In the three stands (Ewenke 1, Ewenke 2, and Ewenke 3) near the Mergen River, the dominant species was S. krylovii, with Potentilla acaulis, Melilotoides ruthenica and Amblynotus rupestris. The Ewenke-1 stand, which was closest to the river, was dominated by P. acaulis and S. krylovii, which formed two vertical layers in the stand. In the Ewenke 2 and Ewenke 3 stands, S. krylovii was dominant and the SDR of $P$. acaulis was not high compared to the heavily grazed stands. The stand Ewenke 3 was lightly grazed and S. krylovii was dominant, with A. cristatum, Poa pratensis and L. chinensis also present. In the stands at Xiertala and Hake, L. chinensis was the dominant species. Many species characteristic of the forest steppe were recorded. In Xiertala, 47 species, the largest number of species recorded at any of the study sites, were recorded in six $1 \mathrm{~m}^{2}$ quadrats. Mean vegetation height and coverage were $17.0 \mathrm{~cm}$ and $85 \%$. Pulsatilla tenuiloba, B. scorzonerifolium, P. pratensis, S. krylovii and C. korshinskyi were high ranking species, and L. pumilum and Veronica incana were unique to the stand.

In the stand at Hake, 44 species were recorded in six quadrats of $1 \mathrm{~m}^{2}$ and vegetation coverage was $94 \%$. The mean vegetation height was $25.3 \mathrm{~cm}$, which was the highest at any of the study sites. The dominant species was $L$. chinensis and $S$. centauroides, B. inermis, Galium verum, Thalictrum squarrosum and $C$. pediformis were all present with high SDR. S. krylovii had a relatively low SDR value.

In the Hulunbeier grasslands, S. krylovii and L. chinensis were the dominant species with the latter species increasing in light grazing stands. In stands subjected to under more severe and heavy grazing pressure, S. krylovii and L. chinensis was gradually replaced by $P$. acaulis and A. polyrhizum.

\section{Floristic Composition of Heavily and Lightly Grazed Stands at} the Mergen River Site

The floristic composition of the Mergen River stands exposed to light and heavy grazing is given in Table 3 . In the lightly grazed stand, 39 species including three unidentified species were recorded in the five $1 \mathrm{~m}^{2}$ quadrats. The stand was dominated by $S$. krylovii and included $L$. chinensis, $A$. cristatum and $P$. pratensis, the height and coverage of which were $30.3 \sim 50.4 \mathrm{~cm}$ and $94 \%$, respectively. In the heavily grazed stand, 25 species were recorded in the ten 1 $\mathrm{m}^{2}$ quadrats dominated by $S$. krylovii. The plant height of the dominant species and vegetation coverage were $40.2 \mathrm{~cm}$ and $78 \%$, and coverage by $P$. acaulis was large. The soil hardness and soil water contents were $18.4 \mathrm{~mm}$ and $12.1 \%$ in Ewenke 3 and $18.8 \mathrm{~mm}$ and $16.0 \%$ in Ewenke 1, respectively. The difference between water content at the sites was significant (Student $t$-test, $<0.05$ ). The mean height of the highest $S$. krylovii plants was $50.4 \mathrm{~cm}$ in the lightly grazed stand and $40.2 \mathrm{~cm}$ in the heavily grazed stand. The plant heights of $L$. chinensis, A. cristatum and P. pratensis in the lightly grazed stand at Ewenke 3 were $10 \mathrm{~cm}$ higher than the heights of the heavily grazed stand. The SDR of the above-mentioned species and $A$. frigida and A. tenuissimum decreased in response to grazing. Conversely, the SDRs of $P$. acaulis, S. adpressa, S. centauroides, Silene repens and $A$. rupestris all increased with grazing intensity. 
Table 2. General floristic composition of the Hulunbeier grasslands

\begin{tabular}{|c|c|c|c|c|c|c|c|c|c|}
\hline & \multirow[b]{2}{*}{ Species } & \multicolumn{8}{|c|}{ Summed dominance ratio (SDR) } \\
\hline & & Saihantala & Dalai & Aoerjin & Ewenke 1 & Ewenke 2 & Ewenke 3 & Xiertala & Hake \\
\hline 1 & Stipa krylovii & 38.6 & 100.0 & 81.9 & 79.4 & 100.0 & 100.0 & 60.3 & 14.8 \\
\hline 2 & Leymus chinensis & 48.5 & 89.4 & 100.0 & 47.2 & 30.7 & 59.2 & 100.0 & 97.0 \\
\hline 3 & Allium tenuissimum & 14.5 & 55.4 & 52.7 & 18.3 & 38.8 & 38.0 & 42.8 & 17.9 \\
\hline 4 & Carex korshinskyi & 71.3 & 48.3 & 68.1 & 41.8 & 50.2 & 44.1 & 63.7 & 48.7 \\
\hline 5 & Cleistogenes squarrosa & 8.2 & 25.6 & 55.6 & 41.3 & 44.6 & 46.3 & 39.4 & 24.3 \\
\hline 6 & Potentilla bifurca & 30.7 & 13.6 & 17.0 & 30.6 & 12.4 & 41.0 & 14.1 & 41.0 \\
\hline 7 & Sibbaldia adpressa & 12.2 & 3.9 & 20.6 & 33.2 & 37.5 & 22.2 & 12.5 & \\
\hline 8 & Salsola collina & 41.1 & 28.4 & 48.6 & & & & 5.9 & \\
\hline 9 & Chenopodium acuminatum & 15.4 & 70.4 & 42.5 & & 20.5 & & & 14.2 \\
\hline 10 & Caragana stenophylla & 26.4 & 14.3 & & & & & & \\
\hline 11 & Asparagus dauricus & 21.6 & 5.1 & & & & & & \\
\hline 12 & Allium polyrhizum & 100.0 & & & & & & & \\
\hline 13 & Euphorbia humifusa & 36.7 & & & & & & & \\
\hline 14 & Artemisia pectinata & 13.9 & & & & & & & \\
\hline 15 & Allium bidentatum & & 43.6 & 48.4 & 38.0 & 41.0 & 43.9 & 37.8 & 7.9 \\
\hline 16 & Agropyron cristatum & & 5.4 & 40.9 & 42.0 & 45.6 & 59.0 & 9.7 & 37.7 \\
\hline 17 & Artemisia frigida & & 4.6 & 37.4 & 3.6 & 47.5 & 49.7 & 40.9 & 15.5 \\
\hline 18 & Bupleurum scorzonerifolium & & 4.5 & 58.2 & & 19.4 & 17.4 & 67.8 & 20.8 \\
\hline 19 & Potentilla verticillaris & & 4.0 & 42.1 & 7.5 & & 7.7 & 19.6 & 20.7 \\
\hline 20 & Melilotoides ruthenica & & 7.7 & 16.9 & 40.0 & 39.5 & 44.8 & & \\
\hline 21 & Koeleria cristata & & & 39.9 & 26.9 & 12.4 & 40.4 & 48.3 & 22.8 \\
\hline 22 & Potentilla acaulis & & & 11.9 & 69.9 & 39.2 & 46.9 & 29.9 & 6.8 \\
\hline 23 & Serratula centauroides & & & 37.1 & 40.1 & 37.6 & 7.8 & & 76.1 \\
\hline 24 & Poa pratensis & & & 9.3 & 5.0 & & 53.7 & 64.1 & 51.6 \\
\hline 25 & Silene repens & & & & 31.4 & 26.1 & 7.8 & 24.1 & 6.4 \\
\hline 26 & Iris tigridia & & & & 41.9 & 39.4 & 42.0 & 39.7 & \\
\hline 27 & Amblynotus rupestris & & & & 31.6 & 12.9 & 7.5 & & \\
\hline 28 & Caragana microphylla & & 47.1 & 5.0 & & & & & \\
\hline 29 & Saussurea salicifolia & & 22.5 & 11.0 & & & & & \\
\hline 30 & Haplophyllum dauricum & & 9.4 & 11.6 & & & & & \\
\hline 31 & Euphorbia esula & & 4.9 & 27.3 & & & & & \\
\hline 32 & Ptilotrichum tenuifolium & & 4.3 & 21.4 & & & & & \\
\hline 33 & Chenopodium aristatum & & & 59.6 & & & & & \\
\hline 34 & Stipa grandis & & & 44.9 & & & & & \\
\hline 35 & Festuca dahurica & & & 22.3 & & & & & \\
\hline 36 & Silene jenisseensis & & & 16.3 & & & & & \\
\hline 37 & Taraxacum dissectum & & & 11.9 & & & & & \\
\hline 38 & Filifolium sibiricum & & & 11.0 & & & & & \\
\hline 39 & Potentilla betonicaefolia & & & 9.9 & & & & & \\
\hline 40 & Artemisia tanacetifolia & & & & & & 16.8 & & \\
\hline 41 & Thymus serphyllum var. asiaticus & & & & & & 7.4 & & \\
\hline 42 & Veronica incana & & & & & & & 43.5 & \\
\hline 43 & Senecio kirilovii & & & & & & & 37.2 & \\
\hline 44 & Vicia cracca & & & & & & & 28.3 & \\
\hline 45 & Achnatherum sibiricum & & & & & & & 9.7 & \\
\hline 46 & Artemisia dracunculus & & & & & & & 9.3 & \\
\hline 47 & Sanguisorba officinalis & & & & & & & 8.3 & \\
\hline 48 & Polygala tenuifolia & & & & & & & 7.9 & \\
\hline 49 & Astragalus adsurgens & & & & & & & 7.7 & \\
\hline 50 & Adenophora coronopifolia & & & & & & & 6.9 & \\
\hline
\end{tabular}


Table 2. Continued.

\begin{tabular}{|c|c|c|c|c|c|c|c|c|c|}
\hline & \multirow[b]{2}{*}{ Species } & \multicolumn{8}{|c|}{ Summed dominance ratio (SDR) } \\
\hline & & Saihantala & Dalai & Aoerjin & Ewenke 1 & Ewenke 2 & Ewenke 3 & Xiertala & Hake \\
\hline 51 & Bromus inermis & & & & & & & & 71.5 \\
\hline 52 & Polygonum divaricatum & & & & & & & & 39.4 \\
\hline 53 & Vicia amoena & & & & & & & & 31.6 \\
\hline 54 & Stipa baicalensis & & & & & & & & 20.2 \\
\hline 55 & Polygonum convolvulus & & & & & & & & 15.9 \\
\hline 56 & Hemerocallis minor & & & & & & & & 7.9 \\
\hline 57 & Taraxacum mongolicum & & & & & & & & 6.3 \\
\hline 58 & Lappula ledowskii & & & & & & & & 6.1 \\
\hline 59 & Viola variegata & & & & & & & & 5.9 \\
\hline 60 & Scorzonera austriaca & 10.4 & 23.9 & 27.3 & & & 25.5 & 37.1 & 21.6 \\
\hline 61 & Pulsatilla tenuiloba & & & 13.8 & & & 24.2 & 72.1 & 30.5 \\
\hline 62 & Allium anisopodium & & 5.7 & 57.0 & & 13.5 & & 9.0 & \\
\hline 63 & Artemisia scoparia & & & & & 7.6 & 10.2 & 32.6 & 20.8 \\
\hline 64 & Oxytropis myriophylla & & & 4.6 & & & 16.8 & 47.8 & \\
\hline 65 & Heteropappus altaicus & & & & 8.0 & & 16.3 & 6.3 & \\
\hline 66 & Astragalus melilotoides & & & 24.7 & & & & 32.1 & 7.9 \\
\hline 67 & Thalictrum squarrosum & & & 15.2 & & & & 15.5 & 60.4 \\
\hline 68 & Convolvulus ammannii & 18.9 & 37.7 & & & 26.8 & & & \\
\hline 69 & Oxytropis hirta & & 8.2 & & 18.8 & 6.5 & & & \\
\hline 70 & Cymbaria dahurica & & 5.0 & 11.3 & & & & 38.5 & \\
\hline 71 & Galium verum & & & & & & 24.2 & 46.2 & 62.9 \\
\hline 72 & Schizonepeta multifida & & & & & & 8.3 & 38.9 & 20.3 \\
\hline 73 & Allium ramosum & 43.4 & & 34.6 & & & & & \\
\hline 74 & Saposhnikovia divaricata & & & 14.8 & & & & 40.7 & \\
\hline 75 & Iris lactea var. chinensis & & & 13.7 & & & & & 32.0 \\
\hline 76 & Clematis hexapetala & & & 4.9 & & & & & 8.3 \\
\hline 77 & Astragalus galactites & & & 21.5 & & & & & 6.3 \\
\hline 78 & Thermopsis lanceolata & & 8.1 & & & & & & 6.7 \\
\hline 79 & Potentilla tanacetifolia & & & & & & 7.7 & & 8.4 \\
\hline 80 & Plantago depressa & & & & & & 7.8 & & 6.7 \\
\hline 81 & Carex pediformis & & & & & & & 7.9 & 46.2 \\
\hline 82 & Dianthus chinensis & & & & & & & 14.1 & 17.8 \\
\hline 83 & Lilium pumilum & & & & & & & 51.0 & 10.9 \\
\hline 84 & Adenophora stenanthina & & & & & & & 20.1 & 9.4 \\
\hline 85 & Adenophora crispata & & & & & & & 17.7 & 6.3 \\
\hline 86 & Chenopodium album & & & & 3.8 & & & & \\
\hline 87 & Iris tenuifolia & & 12.5 & & & & & & \\
\hline 88 & Taraxacum sp. & & & & 13.9 & 17.5 & 7.3 & 23.6 & \\
\hline 89 & Astragalus sp. & & & & & & 7.3 & & \\
\hline 90 & Plantago sp. & & & & 3.5 & 11.7 & & & \\
\hline 91 & Oxytropis sp. & & & & 7.3 & & & 33.9 & \\
\hline 92 & Ixeris sp. & & & & & & 15.9 & & \\
\hline 93 & Juncus sp. & & & & & & 9.3 & & \\
\hline 94 & Chenopodium sp. & & & & & 12.4 & & & \\
\hline 95 & Silene sp. & & & & & & 8.2 & & \\
\hline 96 & Unidentified species 1 & & & & & & & 6.3 & \\
\hline 97 & Unidentified species 2 & & & & & & 9.0 & & \\
\hline 98 & Unidentified species 3 & & & & & & 7.9 & & \\
\hline 99 & Unidentified species 4 & & & & & & 8.1 & & \\
\hline & Number of species & 17 & 29 & 43 & 25 & 26 & 39 & 47 & 44 \\
\hline
\end{tabular}


Table 3. Floristic composition of the light grazed and heavy grazed stands in Mergen River (MR3 and MR1) with SDR, mean height (H:cm) and mean cover $(\mathrm{C})$

\begin{tabular}{|c|c|c|c|c|c|c|}
\hline \multirow{2}{*}{ Species } & \multicolumn{3}{|c|}{ Light grazed stand (MR3) } & \multicolumn{3}{|c|}{ Heavy grazed stand (MR1) } \\
\hline & SDR & $\mathrm{H}$ & $\mathrm{C}^{*}$ & SDR & $\mathrm{H}$ & $\mathrm{C}$ \\
\hline Stipa krylovii & 100.0 & 50.4 & 3.80 & 79.4 & 40.2 & 1.40 \\
\hline Leymus chinensis & 59.2 & 32.2 & 0.52 & 47.2 & 16.0 & 0.07 \\
\hline Agropyron cristatum & 59.0 & 34.0 & 0.36 & 42.0 & 9.6 & 0.09 \\
\hline Poa pratensis & 53.7 & 30.3 & 0.04 & 5.0 & 20.0 & 0.04 \\
\hline Artemisia frigida & 49.7 & 14.0 & 0.81 & 3.6 & 3.0 & 0.04 \\
\hline Potentilla acaulis & 46.9 & 3.6 & 1.28 & 69.9 & 3.9 & 3.60 \\
\hline Cleistogenes squarrosa & 46.3 & 14.9 & 0.36 & 41.3 & 7.1 & 0.23 \\
\hline Melilotoides ruthenica & 44.8 & 13.4 & 0.30 & 40.0 & 6.2 & 0.17 \\
\hline Carex korshinskyi & 44.1 & 14.0 & 0.17 & 41.8 & 9.7 & 0.06 \\
\hline Allium bidentatum & 43.9 & 15.4 & 0.04 & 38.0 & 10.3 & 0.04 \\
\hline Iris tigridia & 42.0 & 12.6 & 0.04 & 41.9 & 10.0 & 0.04 \\
\hline Potentilla bifurca & 41.0 & 9.8 & 0.14 & 30.6 & 5.5 & 0.04 \\
\hline Koeleria cristata & 40.4 & 9.8 & 0.07 & 26.9 & 5.7 & 0.04 \\
\hline Allium tenuissimum & 38.0 & 20.9 & 0.04 & 18.3 & 14.8 & 0.04 \\
\hline Scorzonera austriaca & 25.5 & 13.3 & 0.04 & & & \\
\hline Galium verum & 24.2 & 10.0 & 0.04 & & & \\
\hline Pulsatila tenuiloba & 24.2 & 10.0 & 0.04 & & & \\
\hline Sibbaldia adpressa & 22.2 & 5.0 & 0.04 & 33.2 & 3.7 & 0.06 \\
\hline Bupleurum scorzonerifolium & 17.4 & 14.8 & 0.04 & & & \\
\hline Artemisia tanacetifolia & 16.8 & 10.5 & 0.20 & & & \\
\hline Oxytropis myriophylla & 16.8 & 12.5 & 0.04 & & & \\
\hline Heteropappus altaicus & 16.3 & 10.5 & 0.04 & 8.0 & 7.5 & 0.04 \\
\hline Ixeris sp. & 15.9 & 9.0 & 0.04 & & & \\
\hline Artemisia scoparia & 10.2 & 26.0 & 0.04 & & & \\
\hline Juncus sp. & 9.3 & 19.0 & 0.04 & & & \\
\hline Schizonepeta multifida & 8.3 & 10.0 & 0.20 & & & \\
\hline Silene sp. & 8.2 & 11.0 & 0.04 & & & \\
\hline Serratula centauroides & 7.8 & 8.0 & 0.04 & 40.1 & 7.1 & 0.10 \\
\hline Silene repens & 7.8 & 8.0 & 0.04 & 31.4 & 5.9 & 0.12 \\
\hline Plantago depressa & 7.8 & 8.0 & 0.04 & & & \\
\hline Potentilla verticillaris & 7.7 & 7.5 & 0.04 & 7.5 & 4.5 & 0.04 \\
\hline Potentilla tanacetifolia & 7.7 & 7.0 & 0.04 & & & \\
\hline Amblynotus rupestris & 7.5 & 6.0 & 0.04 & 31.6 & 5.6 & 0.16 \\
\hline Thymus serphyllum var. asiaticus & 7.4 & 5.0 & 0.04 & & & \\
\hline Taraxacum sp. & 7.3 & 4.0 & 0.04 & 13.9 & 1.1 & 0.04 \\
\hline Astragalus sp. & 7.3 & 4.0 & 0.04 & & & \\
\hline Oxytropis hirta & & & & 18.8 & 4.3 & 0.07 \\
\hline Oxytropis sp. & & & & 7.3 & 3.5 & 0.04 \\
\hline Chenopodium album & & & & 3.8 & 5.0 & 0.04 \\
\hline Plantago sp. & & & & 3.5 & 1.5 & 0.04 \\
\hline Unidentified species 1 & 9.0 & 17.0 & 0.04 & & & \\
\hline Unidentified species 3 & 8.1 & 10.0 & 0.04 & & & \\
\hline Unidentified species 2 & 7.9 & 9.0 & 0.04 & & & \\
\hline Number of species & 39 & & & 25 & & \\
\hline
\end{tabular}

*Mean cover is evaluated as 4: $>75 \%$, $3: 74 \sim 50 \%, 2: 49 \sim 25 \%, 1: 24 \sim 5 \%, 0.2: 4 \sim 1 \%, 0.04:<0.9 \%$ 
The relative SDR of C. squarrosa, C. korshinskyi, and Allium bidentatum also increased by grazing.

\section{Relationship between Species Rank and SDR}

As described above, particular species combinations were observed in particular environmental conditions. Among the species examined, a relationship was observed between rank $(r)$ and SDR in a stand. For example, the relationships between rank and SDR in the Manchuria stand is shown in Fig. 5. The relationship can be approximated using the following equation:

$$
\mathrm{SDR}=90.5 \exp (-0.06 r)
$$

$r$ : species rank in SDR.

The relationship was observed also in other study sites. The coefficient and exponent for each study site are given in Table 4. The exponents were -0.13 in Saihantala and -0.12 in Dalai and -0.06 in Aoerjin, Xiertala and Hake. The equation for each site was derived from five randomly selected quadrats. The intensively

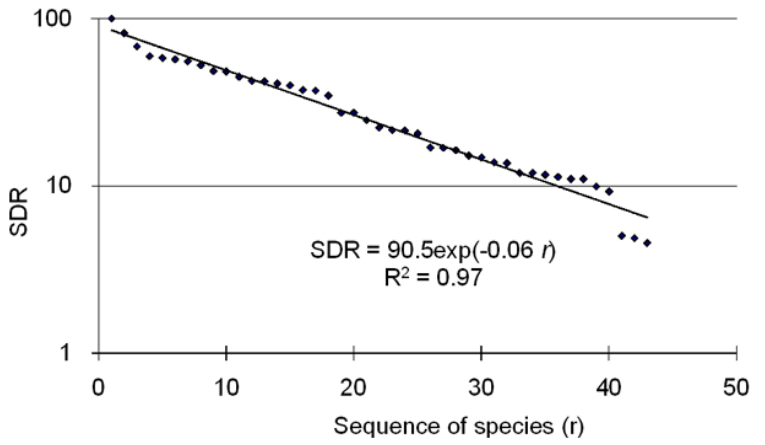

Fig. 5. Relationship between species rank and summed dominance ratio (SDR) for each stand. grazed stands were composed of a small number of species and the exponents are small. In the heavily grazed areas, the stands to the west of Lake Hulun had smaller exponents compared to sites in the east, implying that the stands to the west were grazed more intensively than the stands to the east. These empirical findings were corroborated in the field.

The Shannon-Weaver's index is also provided in the same table, and similar values were obtained in both the lightly and heavily grazed stands. The Shannon-Weaver's index was not sensitive to the degree of grazing pressure.

\section{Plant Biomasses in the Stands}

The relationship between $v$-value $\left(v: \times 100 \mathrm{~cm}^{3}\right)$ and plant biomass (w: g) in Aoerjin in Manchuria is shown in Fig. 6. The plant biomass in the stands was estimated using the equation showing the relationship between the $v$-value and plant biomass (Kawada et al. 2005, Hayashi et al. 2006). For example, the relationship between plant biomass $(w)$ and $v$ value in Aoerjin can be approximated as:

$$
w=0.03 v^{0.96}\left(R^{2}=0.68\right)
$$

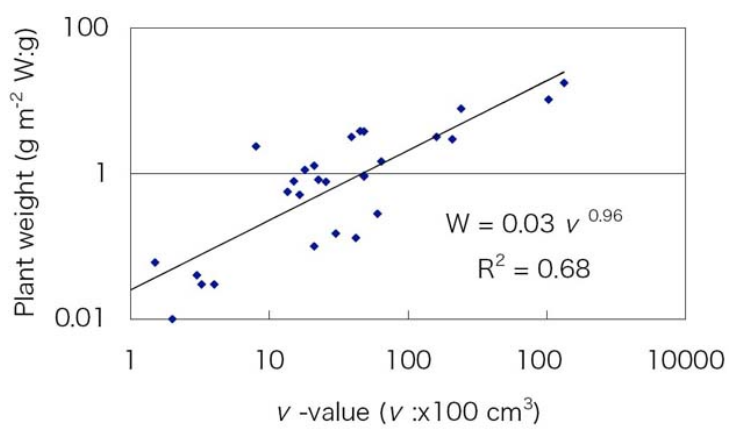

Fig. 6. Relationship between $v$-value of the species and plant weight.

\begin{tabular}{|c|c|c|c|c|c|c|}
\hline & & Species richness $\left(5 \mathrm{~m}^{-2}\right)$ & Coefficient (a) & Exponent (b) & $R^{2}$ & $\mathrm{H}^{\prime}$ \\
\hline & Saihantala & 15 & 91.0 & -0.13 & 0.90 & 1.24 \\
\hline \multirow[t]{4}{*}{ West } & Dalai & 24 & 93.6 & -0.12 & 0.98 & 1.55 \\
\hline & Aoerjin & 43 & 89.4 & -0.06 & 0.99 & 2.07 \\
\hline & Ewenke 1 & 21 & 84.0 & -0.09 & 0.82 & 1.04 \\
\hline & Ewenke 2 & 24 & 86.1 & -0.10 & 0.89 & 0.80 \\
\hline \multirow[t]{3}{*}{ East } & Ewenke 3 & 39 & 76.6 & -0.07 & 0.94 & 0.94 \\
\hline & Xiertala & 47 & 99.6 & -0.06 & 0.96 & 2.40 \\
\hline & Hake & 43 & 76.5 & -0.06 & 0.98 & 2.35 \\
\hline
\end{tabular}

Table 4. Coefficient and exponent of the equation SDR $=\mathrm{a} * \exp (\mathrm{b} * \mathrm{r})$, species richness $\left(5 \mathrm{~m}^{-2}\right)$ and Shannon-Weaver's index $\left(\mathrm{H}^{\prime}\right)$

\footnotetext{
* These equations and species richnesses are calculated by randomly-selected five quadrats.
} 
Once we obtained the coefficient and exponent, we are able to estimate the plant biomass in the stand without the need for destructive sampling in the stand; instead, all that was required was measurements of plant height and coverage. This enabled us to save time and labor measuring plant biomass, which is an important component of field surveys. Using equation (2), the measured and estimated plant biomass from the study sites could be calculated and shown in Table 5. The amount of plant litter and dung in the quadrat are also shown in the Table. The plant biomass values in stands to the west of Lake Hulun were $11.6 \mathrm{~g} \mathrm{~m}^{-2}$ in Saihantala, $28.0 \mathrm{~g} \mathrm{~m}^{-2}$ in Dalai and $63.5 \mathrm{~g} \mathrm{~m}^{-2}$ in Aoerjin. In the stands to the east of the lake, biomass values were $69.5 \mathrm{~g} \mathrm{~m}^{-2}$ in Ewenke-1, $111.2 \mathrm{~g} \mathrm{~m}^{-2}$ in Ewenke 2 and $120.1 \mathrm{~g} \mathrm{~m}^{-2}$ in Ewenke 3. In Xiertala and Hake, values of $136.6 \mathrm{~g} \mathrm{~m}^{-2}$ and $166.2 \mathrm{~g} \mathrm{~m}^{-2}$ were recorded. The difference between measured and estimated values ranged between $1 \%$ and $29 \%$. Increased grazing pressure decreased plant biomass within the stand and standard deviation decreased. Plant litter was $172 \mathrm{~g} \mathrm{~m}^{-2}$ in Xiertala, which was the largest of all of the study sites. Amount of livestock dung varied between stands, and was independent of grazing intensity.

To obtain the stand biomass as a whole, we used the relationship between the plant biomass $(W)$ and $V\left(\mathrm{~cm}^{3}\right)$ value, which is a product of vegetation coverage and plant height in the stand. The $V$ value is separate from the $v$-value, which is a product of plant height and coverage of plant population for each species. Using the $V$-value, we were able to estimate stand biomass without measuring the weight of each species in the stand.

As shown in Fig. 7, this relationship could be approximated using the following equation:

$$
W=0.1 V+10.38 \quad R^{2}=0.91
$$

where $W(\mathrm{~g})$ : plant biomass of a stand, $V\left(\mathrm{~cm}^{3}\right)$ : product of the

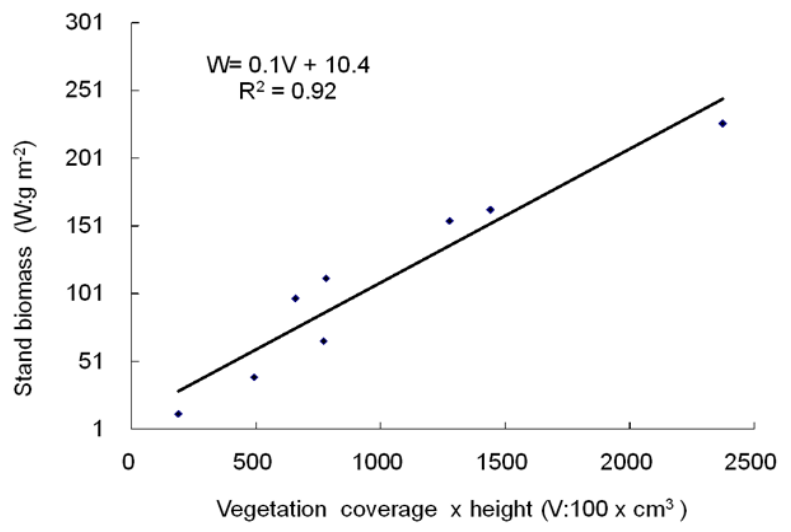

Fig. 7. Relationship between the product of height and coverage $\left(V: \mathrm{cm}^{3}\right)$ and plant biomass $\left(W: \mathrm{g} \mathrm{m}^{-2}\right.$ ) for each stand.

highest plant height and vegetation coverage.

Using equation (3), we were able to collect considerable amounts of data in the field, because time for measuring labor of biomass is saved. The plant biomass values estimated using equation (3) were $29.1 \mathrm{~g} \mathrm{~m}^{-2}$ in Saihantala, $59.6 \mathrm{~g} \mathrm{~m}^{-2}$ in Dalai, $87.5 \mathrm{~g} \mathrm{~m}^{-2}$ in Aoerjin, 247.6. $\mathrm{g} \mathrm{m}^{-2}$ in Hake, $154.5 \mathrm{~g} \mathrm{~m}^{-2}$ in Xiertala, $76.2 \mathrm{~g} \mathrm{~m}^{-2}$ in Ewenke 1, $85.6 \mathrm{~g} \mathrm{~m}^{-2}$ in Ewenke 2 and $138.0 \mathrm{~g} \mathrm{~m}^{-2}$ in Ewenke 3.

\section{DISCUSSION AND CONCLUSION}

We described the floristic composition and biomass of stands in heavily and lightly grazed stands of grassland in Hulunbeier, Inner Mongolia. Even under the same stocking rates, stand quality was observed to vary between stands under different physical conditions such as precipitation and soil. Stand condition is thus determined by a combination of both physical and anthropological factors (Nakamura et al. 2000, Hilbig and Opp 2005). In this study, we

Table 5. The measured and estimated plant biomasses in the stands with standard deviation (S.D.)

\begin{tabular}{|c|c|c|c|c|c|c|c|}
\hline & & \multicolumn{4}{|c|}{ Plant biomass $\left(\mathrm{g} \mathrm{m}^{-2}\right)$} & \multirow{2}{*}{$\begin{array}{c}\text { Litter } \\
\left(\mathrm{g} \mathrm{m}^{-2}\right)\end{array}$} & \multirow{2}{*}{$\begin{array}{c}\text { Dung } \\
\left(\mathrm{g} \mathrm{m}^{-2}\right)\end{array}$} \\
\hline & & Measured (a) & Estimated (b) & S.D. & (a)-(b) / (a) & & \\
\hline \multirow{3}{*}{ West } & Saihantala & 12.3 & 11.6 & 2.5 & 0.05 & 3.8 & 8.7 \\
\hline & Dalai & 39.2 & 28.0 & 7.0 & 0.29 & 17.8 & 29.6 \\
\hline & Aoerjin & 65.9 & 63.5 & 11.8 & 0.04 & 31.4 & 26.6 \\
\hline \multirow{5}{*}{ East } & Ewenke 1 & 97.4 & 69.5 & 14.9 & 0.29 & 16.4 & 9.2 \\
\hline & Ewenke 2 & 112.2 & 111.2 & 27.9 & 0.01 & 33.1 & 16.4 \\
\hline & Ewenke 3 & 154.7 & 120.1 & 15.9 & 0.22 & 100.4 & 4.1 \\
\hline & Xiertala & 162.8 & 136.6 & 24.9 & 0.16 & 172.1 & 2.4 \\
\hline & Hake & 226.5 & 166.2 & 65.9 & 0.27 & 64.0 & 5.6 \\
\hline
\end{tabular}


used the floristic composition, which is thought an integrated indicator of physical and biological factors as criteria for assessing grazing intensity. However, these criteria vary depending on climatic conditions. For example, vegetation coverage is sparse in dryer areas such as areas without grazing in the vicinity of the Gobi desert (Sasaki et al. 2005). Therefore, the above-mentioned criteria can only be applied to stands subjected to the same climatic conditions. In addition, use of these criteria requires that we compare stands subjected to grazing with grazing-free stands.

The steppes in the Hulunbeier region vary from forested and meadow steppe to dry steppe from east to west according to precipitation. The amount of precipitation also affects species dominance, which changes from $L$. chinensis and $S$. grandis in the forest steppe/meadow steppe to S. krylovii in the dry steppe (Liu et al. 1994). It is necessary, therefore, to establish conserved sites to protect the natural steppe vegetation from grazing in each area. By protecting the natural vegetation from grazing, we will be able to evaluate whether grazing and whether sustainable use of the grasslands has been implemented.

In Saihantala, dominant species of the stand has been altered by grazing from $S$. krylovii, which is a dominant in Hulunbeier grasslands, to Allium polyrhizum. By comparing the floristic composition of stands to a protected stand, we are able to predict that the dominant species, L. chinensis, will be replaced by S. krylovii in the Mergen River stands under lightly grazed condition. However, in Xilingole, Inner Mongolia, S. krylovii has increased due to grazing in the grasslands (Nakamura et al. 1998, 2000, Wuyunna et al. 2004). This means that reaction of floristic composition to grazing intensity varies according to physical environmental conditions.

In these stands, grazing was observed to affect the growth-form spectrum in the stand (Nakamura et al. 2000). P. acaulis, which is classified as a prostrate-type species in the growth-form classification of plants, increased in heavily grazed stands. C. squarrosa and $C$. korshinskyi also increased in response to increased grazing pressure on the Hulunbeier steppe.

The situation on the grasslands was not only influenced by grazing intensity and precipitation, but also by cultivation on the steppes. For example, $B$. inermis, a species characteristic of arable land, occurred in stands which formed by soil deposits transported by wind from croplands elsewhere (Kawada and Nakamura 2003); the stand in Hake, in which B. inermis was observed, was surrounded by croplands.

Plant biomass is produced by the plant community, which is determined by physical and anthropological environmental conditions (Chi et al. 1986). In Hulunbeier, to the east of Lake Hulun, the biomass of plant masses measured $111.2 \mathrm{~g} \mathrm{~m}^{-2}$ in Ewenke 2 and $166.2 \mathrm{~g} \mathrm{~m}^{-2}$ in Hake, which is equivalent to $1 \sim 2 \mathrm{t} \mathrm{ha}^{-1}$ obtained in Xilingole, Inner Mongolia (Xiao et al. 1996, Okamoto et al. 2000, Yiruhan et al. 2001). Liu et al. (1994) reported that the plant biomass in the Hulunbeier grasslands measured $156.8 \mathrm{~g} \mathrm{~m}^{-2}$ in $S$. krylovii - C. squarrosa stands $266.3 \mathrm{~g} \mathrm{~m}^{-2}$ in the S. krylovii - L. chinensis stands, which corroborated the findings of our study. Taken together, these findings indicate that the grassland ecosystems hold ca. $450 \sim 1,000 \mathrm{~kg}$ of atmospheric carbon per hector in summer. In addition, the steppe ecosystem is characterized as having a large amount of plant litter ( $\mathrm{Li}$ et al. 2008). In Xiertala, the amount of plant litter measured $172 \mathrm{~g} \mathrm{~m}^{-2}$, which is greater than that of living plants in the stand. This value is equivalent to $580 \mathrm{~kg}$ per hector of atmospheric carbon sequestrated from the atmosphere in the summer period. A portion of the plant litter is expected to be retained as soil organic matter after respiration by soil organisms. If grassland desertification occurs in the steppe region, the sequestrating mechanism of the grassland ecosystems will be lost.

\section{ACKNOWLEDGEMENTS}

We are very grateful to Dr. Zhenghai Li and Ms. Suyoule for their assistance with species identification and arrangement for field studies. We also thank Dr. Takashi Kamijo and Mr. Kazuo Obata for their useful suggestions regarding the script of this paper. Dr. Kenji Tamura, Ms. Akiko Hirata, Ms. Suriguga and Mr. Takashi Kanda are also thanked for their assistance in the field.

\section{LITERATURE CITED}

Burensain B. 2001. Settlement, village formation and the desertification in Inner Mongolia: a case study of the Horchin Area. Journal of Arid Land Studies 11: 13-22. (in Japanese)

Chi Y, Li Y, Ling Y. 1986. Preliminary research of the quantitative relationship between the plant community aerial biomass and the water, temperature conditions in Aneurolepidium chinense steppe community. Research on Grassland Ecosystem 1: 24-37. (in Chinese)

Hayashi I, Kawada K, Akimova A, Nakamura T. 2006. Floristic composition and plant biomass of the grasslands in the vicinity of Pavlodar, Kazakhstan. Grassl Sci 52: 141-149.

Hayashi I, Jiang S, Nakamura T. 1988. Phytomass Production of Grasslands in Xilin River Basin, Xilingol, Inner Mongolia, China. Bull Sugadaira Montane Res Cen 9: 19-31.

HayashiI, Kawada K, Kurosu M, Batjargal A, Tsundeekhuu T, Nakamura T. 2008. Grazing effects on floristic composition and above ground plant biomass of the grasslands in the Northeastern Mongolian steppe. J Ecol Field Biol 31: 115-123.

Hilbig W, Opp C. 2005. The effect of anthropogenic impact on plant and soil cover in Mongolia. Erforsch Boil Ress Mongolei 9: 163-177.

Huang D, Shiyomi M, Chen J, Takahashi S, Hori Y, Yamamuru Y, 
Wang Y. 2004. Spatial heterogeneity of vegetation in Inner Mongolia, China. Grassl Sci 50: 319-328.

Institute of Meteorology and Hydrology of Inner Mongolia 2006. Meteorological Data in Hailar, Inner Mongolia, China.

Kawada K, Nakamura T. 2003. Effects of Aeolian sandy soils on the floristic composition of grassland originate from crop field in semi-arid region under the strong wind condition. Journal of Arid Land Studies 13: 173-181. (in Japanese)

Kawada K, Vovk AG, Filatva OV, Araki M, Hayashi I. 2005. Floristic composition and plant biomass production of steppe communities in the vicinity of Kharkiv, Ukraine. Grassl Sci 51: 205-203.

Kawanabe S, Nan Y, Zhang S, Oshida T, Kou Z, Jiang D, Furuta M, Takada-Oikawa N. 1998. A change of vegetation and soil of the desertified grasslands on the process of recovery 2. At the sites of non-saline meadow and saline meadow. Grassl Sci 45: 149-156.

Li Y, Qingtao M, Xueyong Z, Jianyuan C. 2008. Relationship between fresh leaf traits and leaf litter decomposition of 20 plant species in Kerqin sandy land, China. Acta Ecologica Sinica 28: 24862492.

Liu X, Wei S, Zhang Y, Hu K, Guo X. 1994. The floristic constitution and vegetational characteristic study in Hulunbeier region. Acta Prataculturae Sinica 3: 32-40. (in Chinese)

Nakamura T, Go T, Li Y H., Hayashi I. 1998. Experimental study on the effects of grazing pressure on the floristic composition of a grassland of Baiyinxile, Xilingole, Inner Mongolia. Veg Sci 15: 139-145.

Nakamura T, Go T, Wuyunna, Hayashi I. 2000. Effects of grazing on the floristic composition of grasslands in Baiyinxile, Xilingole, Inner Mongolia. Grassl Sci 45: 342-350.

Nakamura T, Gong Y, Jiang S. 1988. A preliminary study on the cla- ssification of steppe vegetation using Braun-Blanquet's method in some areas of Xilin River Basin in Inner Mongolia. Bull Sugadaira Montane Res Cen 9: 9-17.

Numata M. 1987. Structure of plant community. In: Papers on Plant Ecology. Tokaidaigaku Shuppankai, Kanagawa, pp 50-167. (in Japanese).

Okamoto C, Nakamura M, Kabata K, Wang Y. 2000. Seasonal changes of the aboveground phytomass of a Stipa baicalensis community in Northeast China. Grassl Sci 46: 217-222.

Sasaki T, Okayasu T, Takeuchi K, Jamsran U, Jadambaa S. 2005. Patterns of floristic composition under different grazing intensities in Bulgan, South Gobi, Mongolia. Grassl Sci 51: 235-242.

Wuyunna, Cheng Y, Okamoto K, Taniyama I. 2004. Structural changes in steppe vegetation community according to grazing gradient in semiarid regions of Inner Mongolia, China. J JASS 20: 160-167. (in Japanese)

Wuyunna, Nakamura T, Hayashi I. 1999. Species diversity and phytomass of the grasslands in Inner Mongolia, China. Grassl Sci 45: 140-148. (in Japanese)

Xiao X, Jiang S, Wang Y, Ojima DS, Bonham CD. 1996. Temporal variation in aboveground biomass of Leymus chinensis steppe from species to community levels in the Xilin River Basin, Inner Mongolia, China. Vegetation 123: 1-12.

Yiruhan, Hayashi I, Nakamura T, Shiyomi M. 2001. Changes in floristic composition of grasslands according to grazing intensity in Inner Mongolia. China Grassl Sci 47: 362-369.

Zhou J, Otsuki K, Kamichika M. 1995. Changes of livestock farming in the Inner Mongolia of China. Journal of Arid Land Studies 5: 71-84. (in Japanese)

(Received October 10, 2008; Accepted November 6, 2008) 